\title{
Evaluación de la resistencia mecánica de un hormigón según su porosidad
}

\author{
Evaluation of concrete mechanical strength through \\ porosity
}

\author{
M. OLIVARES(*), J. LAFFARGA ${ }^{(*)}$, C. GALÁN(*), P. NADAL ${ }^{(*)}$ \\ ("Dpto. Construcciones Arquitectónicas I. Escuela Técnica Superior de Arquitectura de Sevilla \\ (")Dpto. Economía Aplicada I. Facultad de C. E. E. de Sevilla
}

Fecha de recepción: 19-II-03

ESPAÑA

\begin{abstract}
RESUMEN
El aumento de huecos o poros de cualquier material, lo mismo que en otras circunstancias, redunda siempre en una merma de sus resistencias mecánicas, al haber menor volumen-masa resistente.

En consecuencia, puede deducirse, que hay una relación entre la compacidad/porosidad y las resistencias mecánicas. En el presente trabajo se estudia una posible correlación entre ambas propiedades del hormigón con independencia de su dosificación, tipo de cemento, granulometria, edad, uso, etc. Las conclusiones obtenidas en la presente investigación permiten al técnico, encargado de una restauración o rehabilitación, determinar la resistencia a compresión de un elemento de hormigón, una vez hallada, de una forma sencilla, la porosidad de una muestra no muy voluminosa, mediante la aplicación de una simple fórmula matemática.
\end{abstract}

\begin{abstract}
The increasing on voids or pores in any material - if the rest of characteristics remains equal-always causes a decrease in their mechanical strength since the ratio volume/resistant mass is lower:

Following all these fact a well known conclusion rises: there is a relationship between compacity/porosity and mechanical strengths. The purpose of this research is to establish a new possible correlation between both concrete properties with independence of the proportions, type of cement, size of grain, age, use. etc. So it can be concluded that the results of this research allow the engineer or architect in charge of a restoration or reparation to determine the compression strength of a concrete element. A first step is to determine the porosity through a rather short number of tests. Subsequently, compression strength will be obtained applying just a mathematical formula.
\end{abstract}

PALABRAS CLAVE: porosidad, resistencia a compresión, hormigón, compacidad, ensayo.

\section{INTRODUCCIÓN}

El trabajo de investigación que se ha desarrollado surge al tomar medidas reales sobre resistencias mecánicas de Hormigones Secos Compactados (HC), que permitieron comprobar que tenían resistencias a compresión
KEYWORDS: porosity, compressive strength, concrete, compactness, test.

\section{INTRODUCTION}

This research was initiated when taking measures of mechanical strengths of High Compacted Dry Concrete. In these tests, concretes of 90 days of age reached compression strength of around $20 \mathrm{MPa}$, with 
cercanas a los $20 \mathrm{MPa}$ a los 90 días de edad, con dosis de cemento inferiores a los $90 \mathrm{~kg} / \mathrm{m}^{3}$, valores que prácticamente se doblaban al año de edad de estos hormigones. Estos datos habían sido obtenidos en los ensayos realizados en el Hormigón Compactado empleado en la ejecución de la Presa tipo gravedad de La Puebla de Cazalla, para lo cual habían pedido el asesoramiento técnico del profesor D. José Laffarga, experto en este tipo de hormigones. Para determinar la porosidad se utilizaron los trozos de los testigos, después de rotos, siguiendo el procedimiento ASTM C-642, que puede ensayarse con muy pocos medios y $\sin$ necesidad de personal especializado.

Estos datos, venían a confirmar, aunque de una forma más contundente, lo que ya se había comprobado con los estudios realizados con el Hormigón Proyectado, en la tesis doctoral «El Hormigón Proyectado. $\mathrm{Su}$ aplicación a los cerramientos de edificación» (1), que las grandes resistencias en estos hormigones proyectados venían justificadas por su alto grado de compactación.

En base a todos estos datos se llega a la conclusión, ya conocida sin embargo, de que hay una relación entre la compacidad/porosidad y las resistencias mecánicas. En consecuencia, nos pareció interesante establecer una posible correlación entre ambas propiedades del hormigón con independencia de su dosificación, tipo de cemento, granulometría, edad, uso, etc., planteando, con estas premisas, el trabajo de investigación.

\section{RELACIÓN ENTRE POROSIDAD Y RESISTENCIA DE UN HORMIGÓN}

\subsection{La porosidad en los materiales}

La decisiva influencia de la porosidad de un material en su comportamiento es admitida sin duda alguna, e incluso Neville (2), en 1986, piensa que la naturaleza de la materia sólida no es lo que importa, sino su cuantía compacta, y relaciona resistencias mecánicas relativas con porosidad de materiales tan diferentes como son el acero, acero inoxidable, yeso, alúmina sinterizada y circonio.

En los materiales se distingue entre la porosidad absoluta o real y la porosidad relativa o aparente, que es también la porosidad referida a los poros accesibles o abiertos al exterior. La porosidad absoluta es el valor de la relación entre el «volumen de los huecos en un material» y el «volumen total» del mismo. Esta porosidad es muy difícil de medir directamente, ya que al no ser todos los huecos o poros accesibles desde el exterior, para determinar su volumen, hay que triturar completamente el material o realizar complejas cement rates under $90 \mathrm{~kg} / \mathrm{m}^{3}$. This strength was nearly doubled after a year in the same concretes. These results had been obtained for tests done to the High Compacted Dry Concrete used for the dam erected in La Puebla de Cazalla (Seville, Spain). Professor José Laffarga, who was an expert in this type of concrete, was technical assistant there. After compression tests, the pieces were used to determine the porosity according to ASTM C-642. This test can be done with very short equipment and no specialized workers.

These results confirmed, with a more conclusive nature, the conclusions of another study in sprayed concrete, the PhD Thesis "El Hormigón Proyectado. Su aplicación a los cerramientos de edificación» (Sprayed concrete. Applications for cladding of building) (1). The conclusion was that the high strengths of sprayed concreted was caused by its high compact degree.

Following all these fact a well known conclusion rises: there is a relationship between compacity/porosity and mechanical strengths. So it was considered to be interesting to establish a new possible correlation between both concrete properties with independence of the proportions, type of cement, size of grain, age, use. etc. And this was the starting point of this research.

\section{RELATIOSHIT BETWEEN POROSITY AND STRENGTH IN CONCRETE}

\subsection{Porosity of materials}

The important influence of a material's porosity in its performance it well known and admitted. Nerville (2) in 1986 establishes that solid nature of a material is not as important as its compactness and relates mechanical strengths with porosity in different materials such as steel, stainless steel, plaster, aluminium and zirconium.

For any material we have to distinguish between absolute or real porosity and, relative also called open or apparent porosity. This relative porosity is the one related to accessible pores or those open on the outside. Absolute porosity is the relationship between the voids volume in a material, and its total volume. This porosity is very difficult to measure because the pores are not accessible form the outside. To determine the volume of the pores or voids, it is necessary to pulverize completely the material or to make complex 
observaciones, empleando métodos de adsorción con gas, porosímetros de mercurio, con o sin presión, y mediciones a escala microscópica. La porosidad abierta es de más fácil determinación y se suele medir directamente mediante ensayos de absorción con agua.

\subsection{La porosidad en el hormigón}

De manera elemental el hormigón es un material compuesto, en el que la pasta de cemento recubre y une granos de áridos. Y como dice Hummel (3), en el hormigón no puede esperarse una compacidad total, ya que está compuesto de materias granuladas y pulverulentas que, a su vez, poseen cierta porosidad propia; en consecuencia, puede afirmarse que "no hay ningún hormigón sin poros".

En el compuesto hormigón, sus poros o huecos, dentro de un amplio intervalo de tamaños, pueden estar más o menos llenos de agua o aire, sea en la masa de la pasta de cemento hidratada, en la propia aureola de transición o interfase pasta-árido, e incluso en el interior de los granos de árido. Tanto las fisuras y poros iniciales, como los que se pudieran producir al deshacerse el material débil, bajo los granos de los áridos del hormigón endurecido, no suelen presentar una morfología regular y además, casi siempre, son de dimensiones apreciables, incluso visualmente. Dentro de la masa de un hormigón, por muy compactado que esté, siempre será posible la observación de poros, generalmente con forma aproximadamente esférica, que quedan llenos de aire, y que se han producido accidental o intencionadamente, impidiendo que se escape aire de la mezcla durante el amasado y puesta en obra del hormigón, atrapándolo y distribuyéndolo en pequeñas burbujas formadas por efecto de ciertos aditivos (aireantes). Los autores de los primeros trabajos experimentales sobre la pasta hidratada, al observar cómo las probetas de pasta y también las de mortero ganaban o perdían peso, alternativamente al humedecerse y al secarse, tomaron el fenómeno como una clara evidencia del carácter poroso de estos materiales, que tantas veces era directamente observable. De acuerdo con diversos autores se puede establecer como clasificación de los poros en las pastas la expresada en la Tabla I. gas adsorption tests, mercury porosimeters under pressure or not and microscopic measurements. Open porosity is easier to determine, directly through water adsorption tests.

\subsection{Concrete porosity}

Concrete can be described in an elemental way as a composite in which the cement mortar covers and joins aggregates grains. And it has been said, Hummel (3), that a total compact cannot be expected for concrete, as it is composed of granulated and powered materials that have certain porosity themselves. So it can be asserted that there is not concrete without voids.

Pores or voids in a concrete composite can be included in a wide range of different sizes, appear more or less filled with water or air, be in the cement hydrated paste, in the transition aureole or paste-grain interface, or even inside the aggregate grain. Both initial fissures and pores and those produced when the softer material gets destroyed under the grains of hardened concrete; don't usually have a regular shape. More often they have a considerable dimension, noticeable just at a glance. No matter how well compacted a concrete may be, voids will always be detected inside its mass. These pores have a rather spherical shape and are filled up with air. They have been produced accidentally or deliberately, but prevent the air to escape during the mixing and lying process of the concrete. The air is trapped and distributed in little bubbles formed due to the effect of certain additives. The authors of the first experimental works on the hydrated paste, when observing how both paste and mortar specimens increased or decreased their weight when wetting or drying respectively, understood this phenomena as a clear evidence of the porosity of these materials, which was also directly noticeable. According to these authors paste pores can be classified as follows in Table I.

TABLA I/TABLE I

Poros en las pastas

Pores in pastes

\begin{tabular}{|cc|}
\hline DENOMINACIONES & RADIOS EN $\AA$ \\
\hline DENOMINATIONS & RADIOUS IN A \\
\hline $\begin{array}{c}\text { Poros gruesos en la pasta } \\
\text { Thick pores in the paste } \\
\text { Macroporos capilares } \\
\text { Capillary macropores } \\
\text { Mesoporos capilares } \\
\begin{array}{c}\text { Capillary mesopores } \\
\text { Microporos o poros del gel } \\
\text { Capillary micropores or gel pores }\end{array}\end{array}$ & $>10.000$ \\
\hline
\end{tabular}


Como poros del hormigón también deben contarse con los propios de los áridos, cuyas características son tan importante para el hormigón, del que vienen a constituir el $75 \%$ de su volumen. Los materiales que se utilizan como áridos convencionales presentan porosidades del 0 al 20\%, aunque los áridos ligeros de forma natural o artificial llegan a presentar porosidades mucho más altas, del 30 al 50\% (4).

Según K.D. Nekrasov (5), en los hormigones se registran porosidades relativas de hasta el $20-30 \%$ y una absorción en agua entre el 10 y el $20 \%$. Otros autores afirman que el grado de absorción de los hormigones suele oscilar entre el 15-20\%, aunque también se han registrados valores entre el $2-6 \%$.

\subsection{Medida de la absorción en agua del hormigón}

Las medidas de absorción en los hormigones se realizan desecando previamente las probetas que se ensayan hasta peso constante, para sumergirlas luego en agua, anotando después su peso, como en el método de ensayo inglés (6). La penetración del agua en el hormigón se acelera sometiendo a las probetas desecadas y luego de sumergidas en agua a un tratamiento de algunas horas en agua hirviendo (ASTM C-642), y también por aplicación de un vacío previo antes de ponerlas en agua (7). Según los tratamientos, duración de inmersión en agua, etc., se miden diferentes grados de absorción y, por consiguiente, diferentes porosidades en los hormigones.

La relación entre la absorción del hormigón y su porosidad no cabe discutirla, aunque pueda variar, lógicamente, de acuerdo con los métodos seguidos para establecer absorción y porosidad.

\subsection{La porosidad del hormigón como medida de su calidad}

Teniendo en cuenta todo lo anterior y contando con las influencias sobre la absorción real de un hormigón, de su curado, de su relación agua/cemento, características de los áridos, tamaños, formas y texturas, contenido en aire, clase de cemento, carbonatación, etc., no resulta difícil pensar en el valor de la absorción del hormigón como un posible, pero principal, índice de calidad y base de comparación entre hormigones.

Ciertamente la indudable sinergia de tantos factores de influencia hace difícil encontrar relaciones altamente significativas entre medidas de absorción y características concretas, pero merece la pena tratar de establecerlas y, en todo caso, pueden bastar las relaciones encontradas, aunque sólo sean aproximadas, ya que estos ensayos sólo necesitan pequeñas muestras,
Grain pores also have to be taken into account. The characteristics of the aggregate are so important for concrete as they reach the $75 \%$ of its total volume. Standard aggregates present porosities from o\% up to a $20 \%$. Natural or artificial light aggregates present a much higher porosity, fro 30 to $50 \%$ (4).

According to K.D. Nekrasov (5), concretes present a relative porosity up to $20-30 \%$. Other authors confirm that adsorption degree in concrete ranges in general between $15-20 \%$. Values of 2-6\% have also been recorded.

\subsection{Water adsorption measurements in concrete}

Adsorption measurements for a concrete are done as follows: Specimens are previously dried until constant weight. Afterwards they are submerged in water, recording the weight according to british standard (6). water penetration into concrete can be accelerated through boiling during some hours the water with the submerged specimens inside (ASTM C-642), and also through vacuum before submerging specimens into the water (7). Depending on the treatment, duration of water immersion, etc. different degrees of adsorption are measured and subsequently different porosities for concrete.

The relationship between concrete adsorption and porosity cannot be discussed, but can vary depending on the method followed to establish adsorption and porosity.

\subsection{Concrete porosity as a quality measurement}

After what has been previously exposed and taking into account the influence on a concrete real adsorption of the hardening process, water/cement ratio, aggregates characteristics, sizes, shapes and textures, void content, cement type, carbonatation, etc. it is not difficult to think about an adsorption value as a quality rate and base for comparison between different concretes.

It is true that the clear synergy of all influence factors makes difficult to find significant relationships between absorption measures and specific characteristics. However, to try it is worthwhile, and, in any case, the presented relationships - although only approximate may be sufficient, since these tests only require small specimens and therefore can be assumed to be non 
con lo que se convierten en métodos prácticamente no destructivos, en los que, por razones obvias, es admisible una menor fiabilidad que en el caso de los ensayos destructivos utilizables para cálculos de precisión y arbitrajes.

Se entiende fácilmente que el aumento de huecos o poros de cualquier material, a igualdad de otras circunstancias, redunda siempre en una merma de sus resistencias mecánicas, al haber menor volumen-masa resistente. La falta de resistencias mecánicas significa también reducción en la durabilidad.

En el caso del hormigón su durabilidad se ve afectada, no sólo, en la merma de sus resistencias al no poder resistir cargas externas, sino que también puede estar afectada negativamente por la posibilidad del desarrollo de tensiones internas, en cuantía y distribución insoportables. Los mecanismos del deterioro mecánico de un hormigón, con la baja de sus resistencias, se explican, en parte, por causa de las tensiones que se originan en sus poros llenos de agua. Dentro de los poros, por causa de la mayor o menor cantidad de agua, pueden originarse presiones o tracciones, para acomodarse las paredes de los capilares del gel, que toman o ceden agua. Pero también pueden aparecer otras tensiones internas y de gran importancia, como las debidas a la congelación del agua interna, a las expansiones por reacciones álcali-sílice, reacciones sulfato-aluminatos, y por otras causas, como las debidas a reducciones de resistencias mecánicas por fisuración.

Smolczyk y Romberg (8), con ensayos de 4 años de duración, han investigado las relaciones entre el volumen de poros en la pasta de cemento y el desarrollo de las resistencias mecánicas del mortero y del hormigón, con diferentes parámetros: tipo de cemento, adiciones, relación agua/cemento, tiempo de curado y condiciones de conservación.

A principios de los 60 , se comienza a admitir la teoría que T. C. Powers propone explicando la evolución de la hidratación de silicatos y aluminatos hidráulicos, por la formación de un gel con poros y capilares, cuya porosidad y permeabilidad son medidas de la evolución del proceso de hidratación y endurecimiento de las pastas de cemento. Las teorías de Powers se basan en el manejo de muchísimos datos experimentales, gran partede los cuales se dieron a conocer a finales de los 40 (9 y 10$)$.

Como forma indirecta de relacionar porosidades y resistencias investigadores como Kondo y colaboradores (11) establecieron la relación entre porosidades y profundidad que alcanza la carbonatación en los hormigones. Más recientemente y a partir de los destructive tests. For obvious reasons, in this type of tests it is required a smaller reliability than in destructive tests employed for precision calculations and arbitration.

From the tests, it can be concluded that the increasing on voids or pores in any material -if the rest of characteristics remains equal-always causes a decrease in their mechanical strength since the ratio volume/resistant mass is lower. The lack of mechanical strength also implies a reduction on the durability.

For the specific case of concrete, its durability is affected not only for the above mentioned lack of strength, but also for the possible development of internal stresses in a great degree and distribution. The mechanisms of the mechanical deterioration of the concrete and the subsequent decreasing of the strength can be party explained according to the stresses originated in its water-filled pores. Due to the water in these pores, pressures and tractions are originated in order to fit the internal walls of the gel capillary, which absorb or expel water. Besides, other internal stresses of great importance can appear, such as those caused by the freeze of the internal water, by the expansion due to alkali-silica or aluminium-sulphate reactions, among other causes such as the reduction of mechanical strength due to fracture.

Carrying out four-year tests, Smolczyk and Romberg (8) have investigated the relationship between the pore volume in concrete and the development of mechanical strength of concrete and cement according to different parameters: type of cement, additives, ratio water/ cement, hardening time, and preservation conditions.

In the beginning of the 60s, it begins the acceptation of the theory by T.C. Powers in which it is explained the evolution of the silica hydration of silicates and hydraulic aluminium due to the formation of a capillary and pores gel. The porosity and permeability of this gel are measures of the evolution of the hydration and hardening process of cement. The theory of Powers is based in a huge number of experimental data, most of them published at the end of the 40s (9 and 10).

As a non-direct mean to correlate porosity and strength, researchers such as Koldo et al. (11) established the relationship between porosity and depth of the carbonation in concretes. More recently, and 
años 70 se han publicado algunas fórmulas empíricas que relacionan resistencias mecánicas y porosidades.

Fagerlund (12), que en 1973 establecía relaciones entre porosidad y resistencias en los hormigones, afirma que los cambios de aquéllas que se producen como consecuencia de la variación de la porosidad durante la hidratación de la pasta son diferentes a los detectados por causa de variaciones en el valor de la relación agua/ cemento de las pastas ensayadas.

Unas relaciones parecidas, equiparando las resistencias mecánicas de las pastas hidratadas con su porosidad total, utilizando una fórmula de tipo exponencial, han sido formuladas más recientemente por Feldman y Beaudoin (13).

Mamillan y Minard (14) han comprobado que la influencia del humo de sílice en el aumento de las resistencias mecánicas de los hormigones aditivados con este material se debe a una importante reducción en las porosidades, que bajan del 13 al $6,5 \%$ por efecto de la adición, anotando también que el poder de absorción por capilaridad baja del 82 al $40 \%$ del volumen capilar. Otra relación entre resistencia mecánica a 28 días y porosidades se había ya establecido en 1982 (15), como resultado de estudios sobre adiciones de humo de sílice (Tabla II).

No obstante lo recogido hasta ahora, pocos trabajos se conocen que correlacionen debidamente porosidades de los hormigones y sus resistencias mecánicas, pese a notables evidencias de relación.

\section{TRABAJO EXPERIMENTAL}

La parte experimental de este trabajo de investigación se ha planteado para intentar relacionar la porosidad de hormigones con sus resistencias mecánicas a compresión, mediante el manejo de muestras no muy voluminosas, intentando establecer las resistencias mecánicas reales en hormigones antiguos principalmente, para decidir sobre aspectos estructurales en obras de rehabilitación y restauro ejecutadas a base de hormigón. after the 70s, several empirical formulations linking mechanical strength and porosity have been published.

In 1973, Fagerlund (12) established a new relationship between porosity and strength in concretes. He claims that the changes in the strength due to the variations in the porosity are different to those due to the variations in the ratio water/cement.

Similar relations have been more recently formulated by Feldman and Beaudoin (13). They employ an exponential formula to link mechanical strength and total porosity.

Mamillan and Minar (14) show that the influence of silica smoke in the increasing of the mechanical strength is due to an important reduction (from 13 to $6.5 \%)$ of the porosity of the concrete. They also state that the absorption capacity decreases from 82 to $40 \%$ of the capillarity volume. Another relationship between mechanical strength after 28 days and the porosity was already established in 1982 (15) as result of tests on silica-smoke additions (see Table II).

Despite the aforementioned contributions, little work has been published linking precisely the concrete porosity and its mechanical strength, although there are significant evidences pointing to that relationship.

\section{EXPERIMENTAL WORK}

The experimental part of this research work has been proposed to link the porosity of the concrete with its compression mechanical strength. For that, small and medium specimens of old concretes have been taken, in order to gain some insights on the structural aspects of concrete-based refurbishment.

TABLA II/TABLE II

Relación entre resistencia a compresión y porosidad según \% de humo de sílice Relationship between compression strength and porosity according to the percentage of silica smoke

\begin{tabular}{|cccc|}
\hline CEMENTO $(\%)$ & HUMO DE SILICE $(\%)$ & R. COMPRESIÓN (Mpa) & POROSIDAD $(\%)$ \\
CEMENT $(\%)$ & SILICA FUME $(\%)$ & COMPRESSION & POROSITY $\%)$ \\
\hline 100 & 0 & 14,9 & 21,8 \\
90 & 10 & 18,6 & 12,2 \\
80 & 20 & 22,7 & 6,6 \\
70 & 30 & 24,0 & 3,6 \\
\hline
\end{tabular}


Nos decidimos a utilizar el método ASTM C-642, que resulta de muy fácil ejecución y tomamos dos medidas de porosidad, derivadas ambas de los procedimientos seguidos en dicha norma. La primera, a la cual llamaremos porosidad $\mathrm{A}$, corresponde a la determinada mediante la absorción de agua de la probeta después de permanecer 48 horas sumergida en agua a temperatura ambiente; y la segunda, a la que denominaremos porosidad $\mathrm{T}$, la que se deduce de la cantidad de agua absorbida luego de someter a las probetas saturadas en agua a un período de 5 horas en agua hirviendo. En ambos casos se calcularon por diferencia de peso entre la probeta saturada y seca.

En la Tabla III se han reunido todos los datos importantes a fin de tener una visión global de las características de las muestras y de los resultados de los ensayos y poder analizar más cómodamente todos los aspectos que puedan incidir en el cálculo de las rectas o curvas de regresión.

En primer lugar analizamos si existe una relación lineal entre la porosidad A (la determinada a partir de la medida del volumen de agua absorbido por la muestra a las 48 horas de inmersión en agua a temperatura ambiente) y la resistencia. Se comprobará si existe una correlación lineal y, a la vista de la bondad del coeficiente de determinación, de los valores críticos de contraste de hipótesis sobre cada parámetro y de los porcentajes de las desviaciones se irán buscando relaciones de un mayor grado.

En cada caso se dará, además de la función de regresión y de los demás datos indicados anteriormente, todas las desviaciones, tanto las absolutas como las relativas, y la desviación relativa media, además de los diferentes porcentajes de probetas que entran en diversos intervalos de desviación.

Posteriormente se repetirán las mismas operaciones con la porosidad $\mathrm{T}$ (la determinada a partir de la medida del volumen de agua absorbido por la muestra después de permanecer 5 horas inmersa en agua hirviendo) y la resistencia.

A la vista de los resultados obtenidos, es preciso hacer un análisis de los mismos, antes de establecer las conclusiones definitivas.

En primer lugar se observa que existe una relación entre la porosidad y la resistencia, siendo dicha relación mayor mientras más se aproxime la porosidad calculada al índice real de huecos de la probeta. Es decir, que las relaciones encontradas para la porosidad denominada «T» (después de mantener la probeta sumergida en agua hirviendo durante 5 horas) son bastante mejores que las resultantes para la porosidad denominada «A»
The method ASTM C-542 has been selected due to its simplicity. Two measures of porosity derived from this method have been take: the first one -porosity $A$ - is defined as water absorbed by the specimen after been sunk in water at room temperature for 48 hours. The second-porosity $T$ - is defined as the water absorbed after boiling the water-saturated specimens for 5 hours. In both cases, the measures were calculated by the weight difference between the dry and the wet specimen.

The main data are given in Table III, in order to get a global perspective of the characteristics of the specimens and the results of the tests, as well as to easily analyse all aspects that may influence the calculations of the regression curves or lines.

First, it is analysed whether a linear relation between the porosity $A$ and the strength. According to the fitness of the coefficient and the critical value of the hypotheses tests for each parameter, and the percentage of deviations, different relationships of higher grade will be sought.

For each case, besides the regression function and the above mentioned data, both absolute and relative deviations are given. Additionally, we give the mean average deviation and the percentage of specimens fitting the deviation intervals.

Finally, the same process is repeated with the relationship between porosity $T$ and the strength.

In view of the results obtained, a series of preliminary observations can be done before establishing the final conclusions.

First, it can be seen that there is a relationship between the porosity and the strength. This relationship grows as closer the calculated porosity is to the real index of voids of the specimen. In other words, the relationships 
TABLA III/TABLA III

Características de las muestras y resultados de los ensayos

Characteristics of the specimens and results of the tests

\begin{tabular}{|c|c|c|c|c|c|c|c|c|c|}
\hline $\begin{array}{l}\text { Identif. } \\
\text { Ident. }\end{array}$ & $\begin{array}{l}\text { Probeta } \\
\text { Specimen }\end{array}$ & $\begin{array}{c}\text { Porosidad } \\
\text { A } \\
(\%) \\
\text { Porosity } \\
A \\
(\%) \\
\end{array}$ & $\begin{array}{c}\text { Porosidad } \\
T \\
(\%) \\
\text { Porosity } \\
T \\
(\%) \\
\end{array}$ & $\begin{array}{c}\mathrm{R} . \\
\text { Compresión } \\
\text { (Mpa) } \\
\text { Compression } \\
S . \\
\end{array}$ & $\begin{array}{c}\text { Edad } \\
\text { (meses) } \\
\text { Age } \\
\text { (months) }\end{array}$ & $\begin{array}{l}\text { Cemento } \\
\text { Cement }\end{array}$ & $\begin{array}{c}\text { Áridos } \\
\text { Aggregates }\end{array}$ & $\begin{array}{c}\text { Tipo } \\
\text { Hormigón } \\
\text { Type of } \\
\text { Concrete }\end{array}$ & $\begin{array}{c}\text { Tipo obra } \\
\text { Type of } \\
\text { work }\end{array}$ \\
\hline 001 & 1 & 7,5 & 8,1 & 64,20 & 72 & CEM I- & $\begin{array}{l}\text { Calizos de } \\
\text { machaqueo }\end{array}$ & $\begin{array}{l}\text { Armado } \\
\text { prefabricado }\end{array}$ & $\begin{array}{l}\text { Ovoides de } \\
\text { saneamiento }\end{array}$ \\
\hline & 2 & 6,9 & 7,2 & 65,06 & & & & & \\
\hline \multirow[t]{3}{*}{ SR001 } & 1 & 12 & 17,9 & 30,1 & 165 & $\begin{array}{l}\text { CEM IIA } \\
\text { V-42,5 }\end{array}$ & $\begin{array}{l}\text { Siliceos } \\
\text { rodados }\end{array}$ & $\begin{array}{l}\text { Armado en } \\
\text { pilares }\end{array}$ & $\begin{array}{l}\text { Edificio de } \\
\text { vivienda }\end{array}$ \\
\hline & 2 & 14,2 & 17,7 & 29,5 & & & & & \\
\hline & 3 & 15,2 & 19,6 & 25,13 & & & & & \\
\hline \multirow[t]{2}{*}{$\mathrm{SROO}^{2}$} & 1 & 13,2 & 15,7 & 34,74 & 42 & $\begin{array}{l}\text { CEM IIA } \\
V-42,5\end{array}$ & $\begin{array}{l}\text { Silíceos } \\
\text { rodados }\end{array}$ & $\begin{array}{l}\text { Armado en } \\
\text { pilares }\end{array}$ & Almacén \\
\hline & 2 & 11,3 & 15,9 & 33,55 & & & & 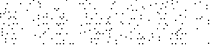 & \\
\hline \multirow[t]{2}{*}{ SR003 } & 1 & 15,4 & 20,5 & 28,03 & 43 & $\begin{array}{c}\text { CEM IIA } \\
\text { V-42,5 }\end{array}$ & $\begin{array}{l}\text { Siliceos } \\
\text { rodados }\end{array}$ & $\begin{array}{l}\text { Armado en } \\
\text { pilares }\end{array}$ & Aeropuerto \\
\hline & 2 & 13,5 & 16,2 & 30,16 & & & & & \\
\hline \multirow[t]{2}{*}{$\mathrm{SR004}$} & 1 & 12,2 & 16,9 & 28,59 & 39 & $\begin{array}{c}\text { CEM IIB } \\
\text { P-32,5 }\end{array}$ & $\begin{array}{l}\text { Silíceos } \\
\text { rodados }\end{array}$ & $\begin{array}{c}\text { Armado en } \\
\text { vigas }\end{array}$ & $\begin{array}{l}\text { Edificio de } \\
\text { vivienda }\end{array}$ \\
\hline & 2 & 13,3 & 18,9 & 25,81 & & & & & \\
\hline \multirow[t]{3}{*}{ SR005 } & 1 & 14,4 & 20,7 & 22,95 & 38 & $\begin{array}{c}\text { CEM IIA } \\
\text { V-42,5 }\end{array}$ & $\begin{array}{l}\text { Silíceos } \\
\text { rodados }\end{array}$ & $\begin{array}{l}\text { Armados en } \\
\text { forjados }\end{array}$ & Aeropuerto \\
\hline & 2 & 11,9 & 14,8 & 29,67 & & & & & \\
\hline & 3 & 14,7 & 18,9 & 25,92 & & & & & \\
\hline SR006 & $\begin{array}{l}1 \\
2 \\
3\end{array}$ & $\begin{array}{r}135 \\
147 \\
11,5\end{array}$ & $\begin{array}{l}18,8 \\
21,1 \\
15,4\end{array}$ & $\begin{array}{l}22,73 \\
23,64 \\
28,23\end{array}$ & 38 & $\begin{array}{l}\text { CEM IIA } \\
\mathrm{V}-42,5\end{array}$ & $\begin{array}{l}\text { Siliceos } \\
\text { rodados }\end{array}$ & Armado en & (4) \\
\hline \multirow[t]{3}{*}{ SR007 } & 1 & 13,8 & 17,7 & 25,65 & 37 & $\begin{array}{c}\text { CEM IIB } \\
\text { P-32,5 }\end{array}$ & $\begin{array}{l}\text { Silíceos } \\
\text { rodados }\end{array}$ & Armado en losas & Bodegas \\
\hline & 2 & 13,3 & 18,8 & 23,99 & & & & & \\
\hline & 3 & 13,8 & 16,3 & 25,31 & & & & & \\
\hline SRO08 & 2 & $\begin{array}{r}17,9 \\
16,6\end{array}$ & $\begin{array}{r}24,8 \\
24,1\end{array}$ & $\begin{array}{l}16,80 \\
14,83\end{array}$ & 42 & $\begin{array}{c}\text { CEM IIB } \\
\mathrm{P}-32,5\end{array}$ & $\begin{array}{l}\text { Siliceos } \\
\text { rodados }\end{array}$ & $\begin{array}{l}\text { Horm. en masa } \\
\text { muros }\end{array}$ & Bodegas \\
\hline \multirow[t]{3}{*}{ SR009 } & 1 & 18,1 & 24,3 & 14,67 & 41 & $\begin{array}{l}\text { CEM IIB } \\
\text { P-32,5 }\end{array}$ & $\begin{array}{l}\text { Silíceos } \\
\text { rodados }\end{array}$ & $\begin{array}{l}\text { Horm. en } \\
\text { masa muros }\end{array}$ & $\begin{array}{l}\text { Nave } \\
\text { almacén }\end{array}$ \\
\hline & 2 & 19,9 & 24,2 & 10,75 & & & & & \\
\hline & 3 & 16,9 & 22,5 & 14,88 & & & & & \\
\hline SR010 & 2 & $\begin{array}{l}12,1 \\
12,3\end{array}$ & $\begin{array}{l}16,0 \\
15,5\end{array}$ & $\begin{array}{r}32,81 \\
32,64\end{array}$ & 480 & $\begin{array}{l}\text { CEM IIB } \\
\text { P-32,5 } \\
\end{array}$ & $\begin{array}{l}\text { Silíceos } \\
\text { rodados }\end{array}$ & $\begin{array}{l}\text { Armado en } \\
\text { pilares }\end{array}$ & $\begin{array}{l}\text { Fábrica de } \\
\text { cemento }\end{array}$ \\
\hline \multirow[t]{2}{*}{ SR011 } & 1 & 12,6 & 16,6 & 28,60 & 180 & $\begin{array}{c}\text { CEM IIB } \\
\text { P-32,5 }\end{array}$ & $\begin{array}{l}\text { Silíceos } \\
\text { rodados }\end{array}$ & Armado en losas & Chalet \\
\hline & 2 & 12,8 & 14,2 & 29,27 & & & & & \\
\hline \multirow[t]{2}{*}{$\mathrm{MCOO} 2$} & 1 & 8,8 & 9,1 & 63,75 & 60 & ${ }_{52,5}^{\text {CEM I- }}$ & $\begin{array}{l}\text { Calizos de } \\
\text { machaqueo }\end{array}$ & $\begin{array}{l}\text { Hormigón } \\
\text { prefabricado }\end{array}$ & $\begin{array}{l}\text { Piezas de } \\
\text { fachada }\end{array}$ \\
\hline & 2 & 8,3 & 8,9 & $62 ; 93$ & & & का & 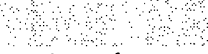 & \\
\hline \multirow[t]{2}{*}{ SR012 } & 1 & 15,2 & 21,9 & 20,85 & 72 & $\begin{array}{c}\text { CEM IIA } \\
\text { V }-42,5\end{array}$ & $\begin{array}{l}\text { Silíceos } \\
\text { rodados }\end{array}$ & $\begin{array}{l}\text { Armado en } \\
\text { pilares }\end{array}$ & $\begin{array}{l}\text { Vivienda } \\
\text { unifamiliar }\end{array}$ \\
\hline & 2 & 14,9 & 20,6 & 22,49 & & & & & \\
\hline \multirow[t]{2}{*}{ SRO13 } & 1 & 11,4 & 14,2 & 37,53 & 42 & $\begin{array}{c}\text { CEM I- } \\
52,5\end{array}$ & $\begin{array}{l}\text { Siliceos } \\
\text { rodados }\end{array}$ & $\begin{array}{c}\text { Armado en } \\
\text { pilares }\end{array}$ & Hangares \\
\hline & 2 & 13,5 & 15,8 & 34,86 & & & & ब & $9 \%$ \\
\hline \multirow[t]{2}{*}{ SR014 } & 1 & 15,3 & 17,3 & 26,32 & 60 & $\begin{array}{c}\text { CEM IIA } \\
\text { V }-42,5\end{array}$ & $\begin{array}{l}\text { Silíceos } \\
\text { rodados }\end{array}$ & Armado en vigas & $\begin{array}{l}\text { Nave } \\
\text { almacén }\end{array}$ \\
\hline & 2 & 11,6 & 17,1 & 26,54 & & & & & \\
\hline \multirow{2}{*}{ SR015 } & 1 & 12,4 & 17,3 & 26,44 & 65 & $\begin{array}{l}\text { CEM IIA } \\
\qquad-42,5\end{array}$ & $\begin{array}{l}\text { Siliceos } \\
\text { rodados }\end{array}$ & $\begin{array}{c}\text { Armado en } \\
\text { pilares }\end{array}$ & $\begin{array}{l}\text { Nave } \\
\text { industrial }\end{array}$ \\
\hline & 2 & 12,8 & 17,2 & 26,77 & $\vdots$ & & & & $\therefore$ \\
\hline
\end{tabular}


(después de mantener la probeta sumergida en agua durante 48 horas), siendo, en todos los casos, la porosidad «T» superior a la porosidad «A».

Por otro lado, hay que hacer la observación, que las relaciones halladas sólo son válidas para unos intervalos determinados. En general, dichos intervalos vendrán establecidos por los valores superiores e inferiores obtenidos de las probetas. En los casos que estamos analizando, para hormigones con porosidades «T» comprendidas entre 7,2 y 24,8 o con porosidades tipo «A» comprendidas entre 6,9 y 19,9. Lo dicho anteriormente, puede comprenderse fácilmente si consideramos que la función posiblemente tenga unos puntos de corte con los ejes coordenados, a partir de los cuales los valores de una de las variables pasa a ser negativo, algo totalmente imposible tanto para la resistencia como para la porosidad. En las funciones parabólicas, por ejemplo, el límite inferior del intervalo coincidirá con el mínimo de la curva, ya que en ese punto se pasaría de una relación inversa a una directa, y, en consecuencia, la resistencia comenzaría a incrementarse al aumentar la porosidad.

Se observa, a la vista de los resultados, que las desviaciones relativas más altas se producen en la mayoría de los casos para porosidades superiores a 22,5 , además de en alguna que otra probeta cuyos resultados se ven claramente discordantes con los de la otra probeta del mismo hormigón; en algunos casos se ha podido ensayar otra probeta comprobándose con ésta última lo indicado anteriormente. No obstante, se han mantenido los valores de dichas probetas para la determinación de las diferentes relaciones, ya que hay que tener en cuenta también en las desviaciones aquéllas que sean debidas a posibles errores en los ensayos o probetas con defectos internos, algunos debidos a deterioros producidos en las mismas al someterse al ensayo de porosidad.

Se ha considerado, sin embargo, interesante determinar las posibles relaciones entre la porosidad « $\mathrm{T}$ » y la resistencia eliminando aquellas probetas cuya porosidad fuera igual o superior a 22,5 (probetas SR008 y SR009), ya que si se presentara alguna vez un caso de este tipo estaríamos, desde luego, ante un hormigón claramente rechazable. Finalmente, también sẹ ha buscado una posible correlación entre ambos tipos de porosidades. Los resultados de estos cálculos son los que se expresan en las curvas que se exponen.

\section{CONCLUSIONES}

A la vista de todo el proceso que antecede se pueden establecer las siguientes conclusiones:

1.- Se confirma, tal como han demostrado anteriormente diversos investigadores, que existe una found for porosity $T$ are rather better that these found for porosity $A$.

On the other hand, it has to be noted that these relationships are valid only for certain intervals. In general, these intervals are given by the higher and lower values obtained by the specimens. For the analysed cases, this holds for concretes with porosity $T$ between 7.2 and 24.8, o porosity $A$ between 6.9 and 19.9. This can be easily understood by taking into account that it is likely that the function crosses the coordinate axes, and after that, the values of one of the variables are negative, which is not possible both for porosity and for strength. For example, in the parabolic functions, the lower limit of the interval coincides with the minimum of the curve, as in this point the inverse relationship turns to be direct, and thus both the strength and the porosity will increase.

In view of the results, it can be said that the highest relative deviations are produced, for most cases, for porosity values higher than 22.5. This is apart for the results in some specimen, which clearly seem not to be concordant with those of the other specimen built using the same concrete. In some cases, it has been possible to employ another specimen to verify the above assertions. However, the values of these specimens have been kept for the calculation of the different relations, since we wish to take into account as well all deviations caused by possible mistakes in the tests, or defective specimens, some of the latter being caused by the porosity test itself.

However, we believe of interest to determine these possible relationships between porosity $T$ and the strength in those specimens with porosity lower that 22.5 (specimens SR008 and SR009), since in this case the concrete will be rejected. Finally, we have sought a relation between the two types of porosities. The results of these calculations are shown in the curves later.

\section{CONCLUSIONS}

According to the whole process, the following conclusions can be drawn:

1- It has been confirmed the inverse relationship 
relación entre la porosidad y la resistencia, y que la misma es de orden inverso.

2.- Esta relación es mucho más ajustada para la porosidad calculada después de mantener la probeta saturada 5 horas en agua hirviendo, que para la calculada con la probeta saturada simplemente, 0 , lo que es lo mismo, después de mantenerla 48 horas sumergida en agua a temperatura ambiente. Entre ambos tipos de porosidades se comprueba que existe una relación de orden positivo o directo, siendo la que mejor se ajusta la de grado parabólico (Figura 1).

Esto hace posible que pueda sustituirse un ensayo por otro con una desviación media definida previamente. Por lo que podrá hacerse el ensayo que determina la porosidad $\mathrm{A}\left(\mathrm{P}_{\mathrm{A}}\right)$ más fácil de realizar $\mathrm{y}$, posteriormente, aplicando la fórmula (I), saber cuál sería la porosidad más ajustada, $\mathrm{P}_{\mathrm{T}}$, sin necesidad de hacer el otro ensayo con agua hirviendo, sabiendo que al aplicarla se obtiene una aproximación tal que, en el 100\% de los casos, según las probetas ensayadas, la desviación sería inferior al $16 \%$, en el $79,48 \%$ de los casos inferior al $10 \%$ y en el $41,03 \%$ de los casos inferior al $5 \%$. between porosity and strength, as previously established by other researchers.

2- This relation is more accurate for the porosity calculated after boiling the water-saturated specimen for 5 hours than for the porosity calculated after sinking the specimen 48 hours at room temperature. Between both types of porosities, it is shown a positive (direct) relationship, being the parabolic relation the one that fits most (see Figure 1).

This makes possible to replace one test by other with a previously defined average deviation. Therefore, it is possible to perform the test for determining the porosity $A\left(P_{A}\right)$, which is easier to carry out, and later apply the formula (I) in order to determine the porosity $P_{T}$ without requiring the additional test employing boiling water. By applying aforementioned formula, it is known that for the $100 \%$ of the cases, the deviation is lower than $16 \%$, lower than $10 \%$ for $79.48 \%$ of the cases, and lower than $5 \%$ for $41.03 \%$ of the cases.

$$
\mathrm{P}_{\mathrm{T}}=-0,038 \mathrm{P}_{\mathrm{A}}^{2}+2,47 \mathrm{P}_{\mathrm{A}}-8,47
$$

3.- La relación entre la resistencia a compresión y la porosidad (cualquiera de las dos consideradas) puede ser de tipo lineal, parabólico o cúbica, siendo esta última la que mejor se ajusta en ambos casos, teniendo
3.- The relationship between the compression strength and the both types of porosities under consideration may be linear, parabolic, or cubic, being the latter the one that better fits both porosities, and hence yielding $a$

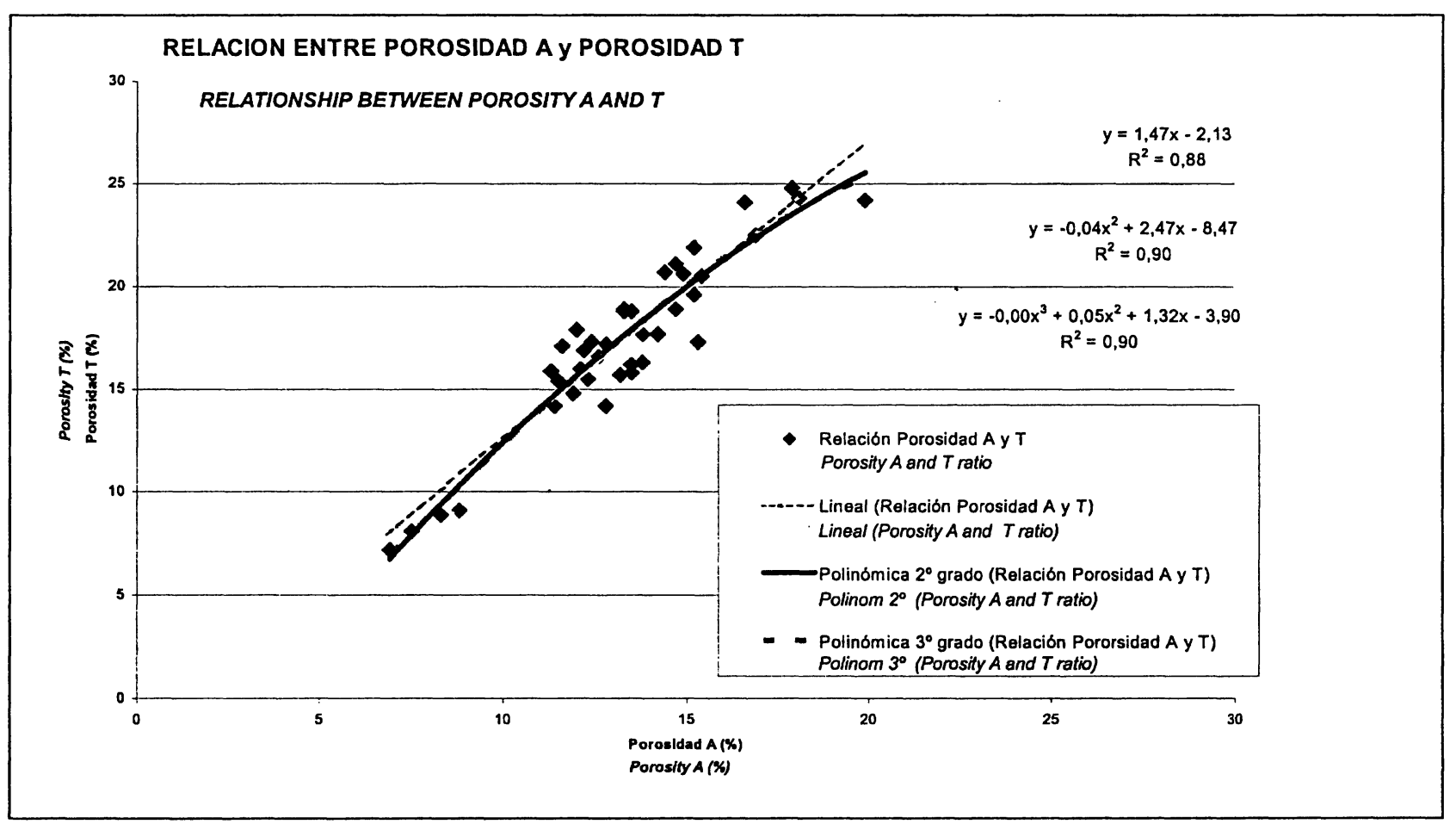

Figura 1.- Relación entre la porosidad "A" (después de mantener la probeta sumergida en agua durante 48 horas) y la poridad "T" (después de mantener la probeta sumergida en agua hirviendo durante 5 horas).

Figure 1.- Relationship between porosities "A" (after sinking the specimen in water for 48 hours) and " $T$ "(after sinking the specimen in boiling water for 5 hours). 
en consecuencia un coeficiente de determinación más alto y una desviación relativa media más baja. Las curvas de ajuste de cuarto grado, o cuárticas, son inaceptables al ser excesivamente altos los valores críticos del contraste de hipótesis de cada uno de los parámetros de las misma. En las Figuras 2 y 3 , se expresan las curvas de grado lineal parabólico o cúbica para ambos tipos de porosidades. higher determination coefficient and a lower relative deviation. Other fitness curves are not acceptable due to the extremely high values for the hypothesis testing for each parameter. In Figures 2 and 3, the curves of types linear, parabolic, and cubic, are given.

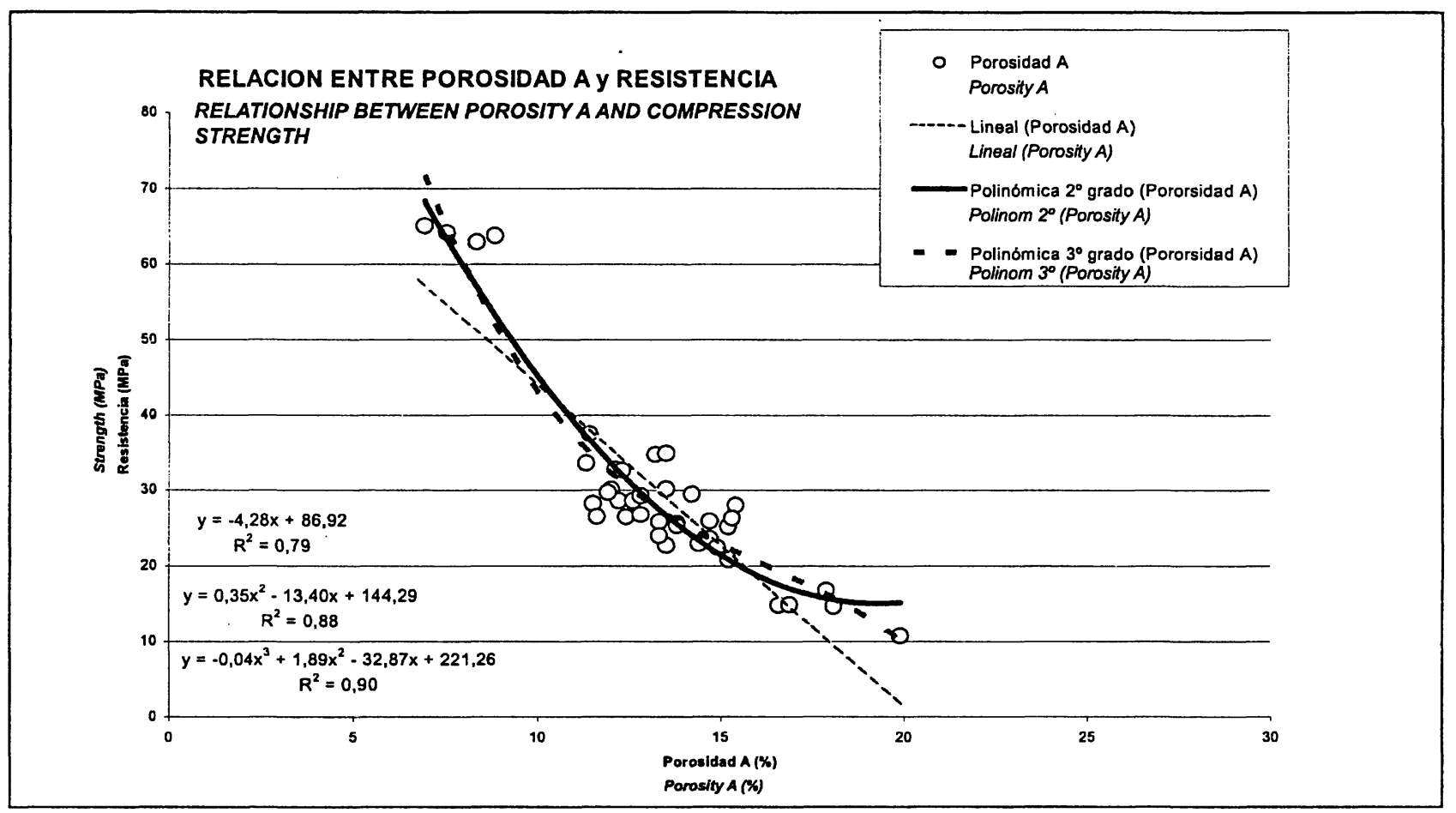

Figura 2.- Relación entre la porosidad "A" (después de mantener la probeta sumergida en agua durante 48 horas) y la resistencia a compresión. Figure 2.- Relationship between porosity " $A$ " (after sinking the specimen in water for 48 hours) and compression strength.

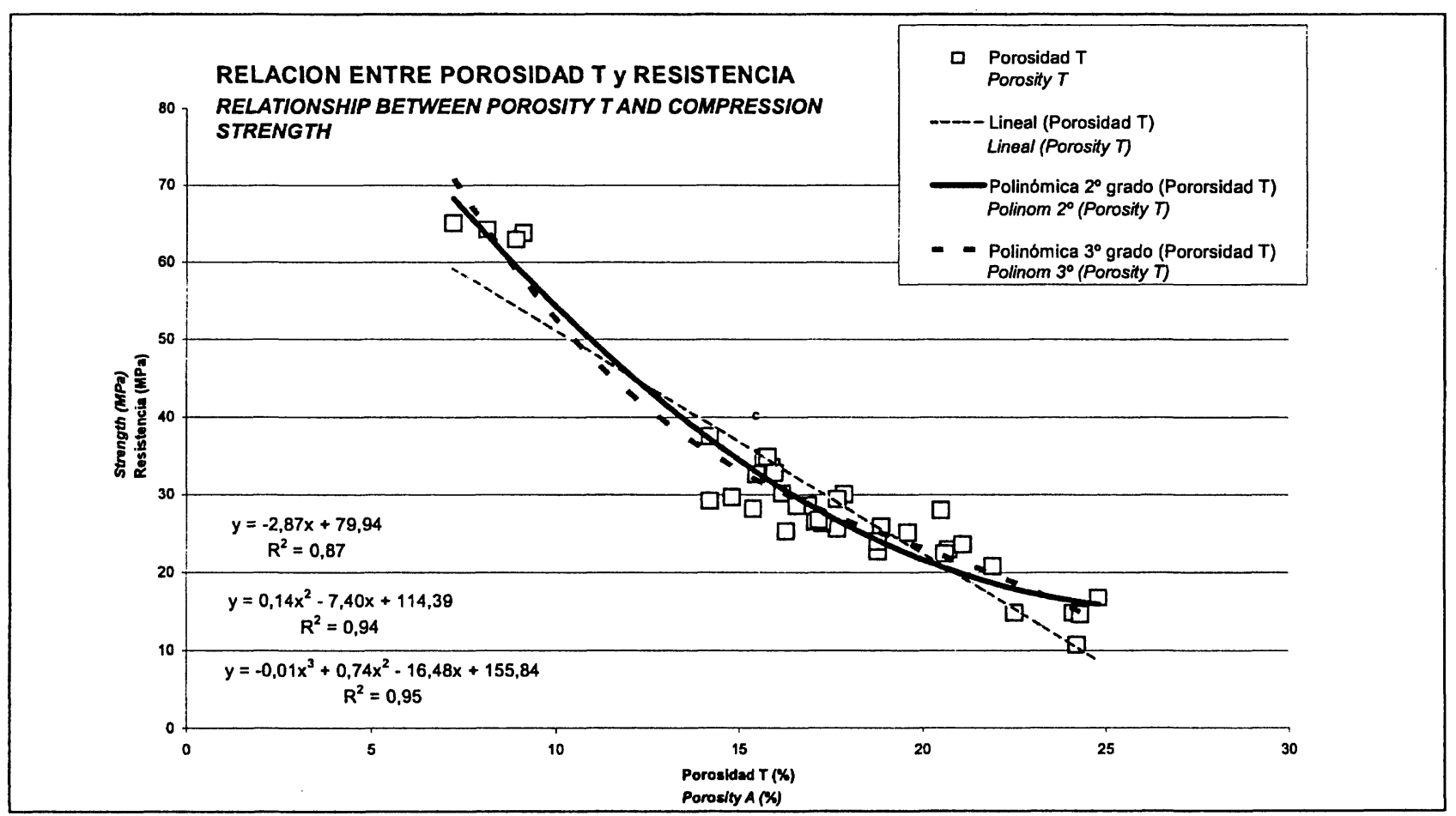

Figura 3.- Relación entre la porosidad "A" (después de mantener la probeta sumergida en agua hirviendo durante 5 horas) y la resistencia a compresión.

Figure 3.- Relationship between porosity "A" (after sinking the specimen in boiling water for 5 hours) and compression strength. 
4.- Las desviaciones relativas más altas se producen, generalmente, para los hormigones con porosidades más altas, ello ha hecho aconsejable buscar funciones de relación para hormigones con porosidades inferiores a unos límites determinados a partir de los cuales el hormigón pueda considerarse desechable. Por tanto, se han establecido unos límites de porosidad (según la determinada después de tener la probeta saturada de hormigón sumergida durante 5 horas en agua hirviendo, según la Norma ASTM C-642) comprendida entre 7,2 y el 22,5\%. Para estos límites existe una correlación mucho más estrecha entre la resistencia a compresión y la porosidad, según puede observarse en las curvas expresadas en la Figura 4. Puede establecerse, en consecuencia, que las relaciones de tipo parabólico y cúbico entre ambas variables son las más adecuadas, sin embargo, al ser la desviación relativa y el coeficiente de determinación de ambas curvas muy similares, se propone la curva parabólica, por ser más sencilla de aplicar, como función de relación entre la porosidad y la resistencia a compresión de un hormigón. Esta fórmula, adecuadamente simplificada, queda como sigue:
4.- The highest relative deviations are usually achieved for these concretes with the highest porosities. Therefore, formulae for concretes with porosities lower than certain values that make the concrete to be unacceptable have been sought. Hence, porosity limits - for the porosity of type $T$ - between 7.2 and $22.5 \%$ have been established. For these limits, there is a close relationship between compression strength and porosity, at it may be observed in Figure 4. Therefore, one can conclude that, although the parabolic and cubic relationships between both variables are the most suitable. The parabolic curve is suggested, since it is easier to apply. This simplified formula is the following:
La aplicación de esta fórmula nos aseguraría que el $100 \%$ de los valores así determinados de la resistencia tendrían una desviación, con respecto a los calculados
The application of this formula guarantees that 100\% of the strengths so calculated will yield a deviation lower than $20 \%$ with respect to those obtained from a

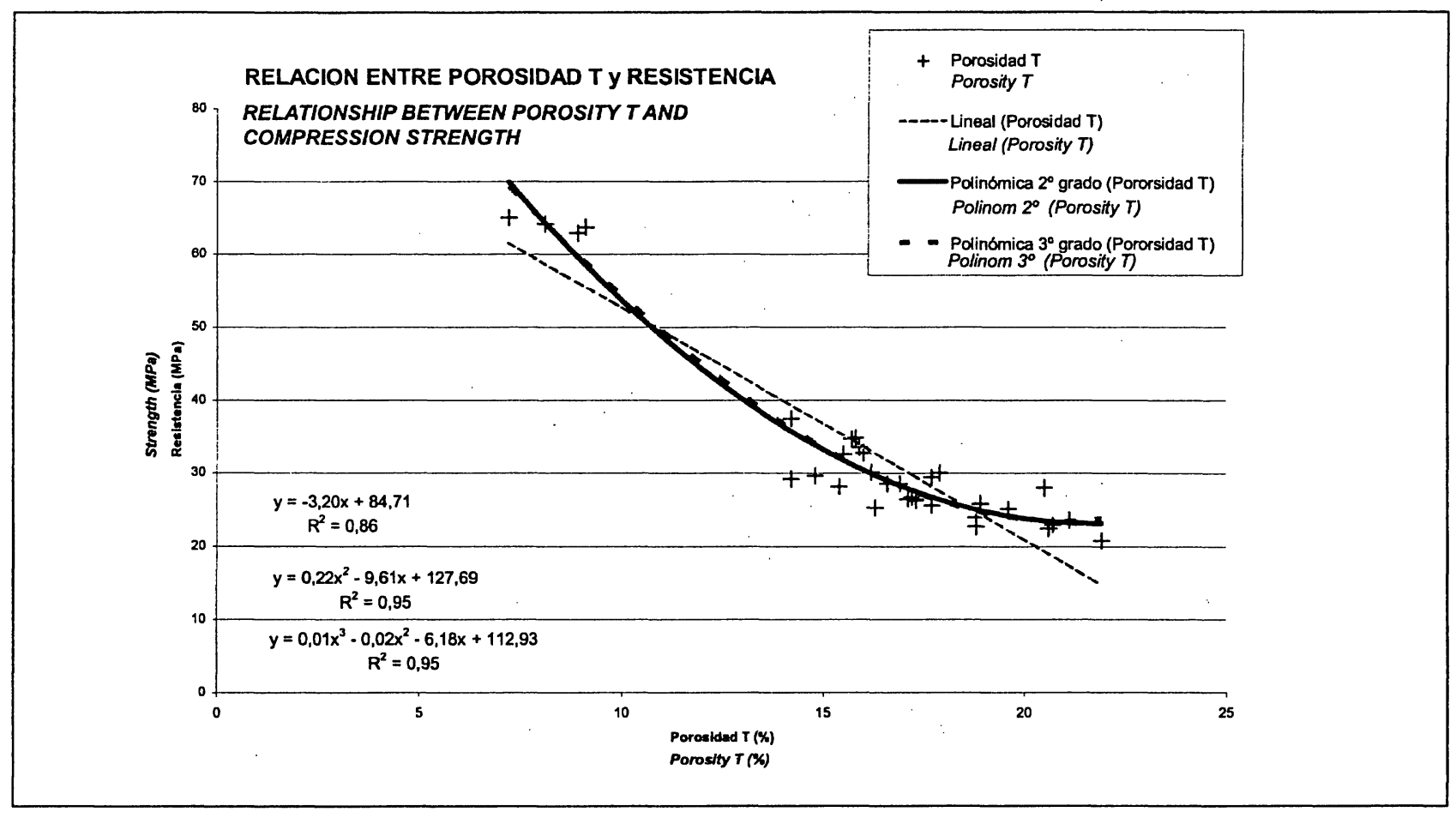

Figura 4.- Relación entre la porosidad "T" (después de mantener la probeta sumergida en agua hirviendo durante 5 horas) y la resistencia a compresión (para porosidades comprendidas en el intervalo de valores 7,2-22,5\%).

Figure 4.- Relationship between porosities " $T$ "(after sinking the specimen in boiling water for 5.hours) and the compression strength (for porosities between the range $7.2-22.5 \%)$. 
mediante ensayos de rotura de probetas, inferior al $20 \%$, el $94,11 \%$ inferior al $15 \%$, el $70,59 \%$ inferior al $10 \%$ y el $50 \%$ inferior al $5 \%$.

Este método de cálculo de la resistencia permitiría a técnicos de restauración conseguir, fácilmente, por medio de ellos mismos, una aproximación de los valores de la resistencia de las piezas de hormigón que tienen que restaurar, sin que por ello se pretenda sustituir los ensayos de laboratorio que posteriormente le darán unos valores de resistencia más exactos. strength test. This deviation will be lower than $15 \%$ for $94,11 \%$ of the tests, lower than $10 \%$ for $70.59 \%$ of the tests, and lower than 5\% for 50\% of the tests.

In the context of refurbishing, this method for strength calculation will allow obtaining an approximation of the strength values of the concretes to be refurbished. Obviously, this will not replace the lab tests, which would yield a more precise strength values.

\section{BIBLIOGRAFÍA}

(1) M. Olivares. El hormigón proyectado. Su aplicación a los cerramientos de edificación. Tesis doctoral, Sevilla, 1986.

(2) A. M. Neville. Propiedades del Hormigón. Una Visión de Conjunto. Parte I. Concrete International. Vol. 8, $\mathrm{n}^{\circ} 2,20-23$ (feb. 1986).

(3) A. Hummel: Prontuario del hormigon, Barcelona, 1966, p.19

(4) J. Grandet y J.P. Ollivier. Orientaciones de los hidratos en contacto con los áridos. Nuevo método de estudio de la interfase cemento-árido. International Symposium Chemistre of Cement. III. París, 1980.

(5) Nekrasov, K.D.: (Citado en Petzold, A. \& Rohrs, M.: Concrete for High Temperatures. London, 1970, p.135).

(6) British Standards Institution: BS 1.881: «Métodos para Ensayar el Hormigón».

(7) ASTM: C 642-75 : «Método de Ensayos normalizados para la Determinación del Peso específico, Absorción y Poros en el Hormigón Endurecido».

(8) H. G. Smolczyc y H. Romberg.: La influencia del tiempo de curado y de las condiciones de conservación sobre el endurecimiento y distribución del tamaño de poros del hormigón. Tonindustrie-Zeitung, $\mathrm{n}^{\circ} 10,349-357$, octubre 1976.

(9) Powers, T. C.: Algunos aspectos de la Física de la Hidratación del Cemento Portland. Journal of Portland Cement Asociation Research and Development Laboratoires, 3 (1), 47-56 (1961).

(10) Powers, T. C. \& Brownyard, T.L. Estudios sobre las Propiedades Físicas de la Pasta Endurecida del Cemento Portland Parte 7: Permeabilidad y Absorción. Proc. American Concrete Institute, 43, 933-1001 (april,1947)

(11) Kondo, R., Diaman, M. \& Akiba, T.: Mecanismo y Cinética de la Carbonatación del Cemento Endurecido. Proc. Simposio sobre Química del Cemento. Tokio 1967, 3, 402-409 (1968)

(12) Fagerlund, G.: Resistencia Mecánica y Porosidad del Hormigón. IUPAC/RILEM intern. Symposium on Pore Structure and Properties of Materials. Vol. 2. Praga, 1973.

(13) Feldman, R. F. \& Beandoin, J.J.: Microestructura y Resistencias Mecánicas del Cemento Hidratado. Proc. Simposio sobre Química del Cemento. Moscow (1974)

(14) Mamillan, M. \& Minard, J.: Durabilidad y Comportamiento de los Hormigones con Adiciones de Humo de Sílice. Jornada de Estudio LCPC-ITBTP, Serie Béton 271. Annales de l'ITBTP, n483, 38-54 (mayo 1.990).

(15) Bürge, T. A.: La densificación de la matriz de cemento mejora la unión y adherencia con las armaduras de acero. Bond in Concrete, Editor. P.Bartos. Essex, 1982, p. 273-288. 


\section{ENCUENTRA LAS DIFERENCIAS}

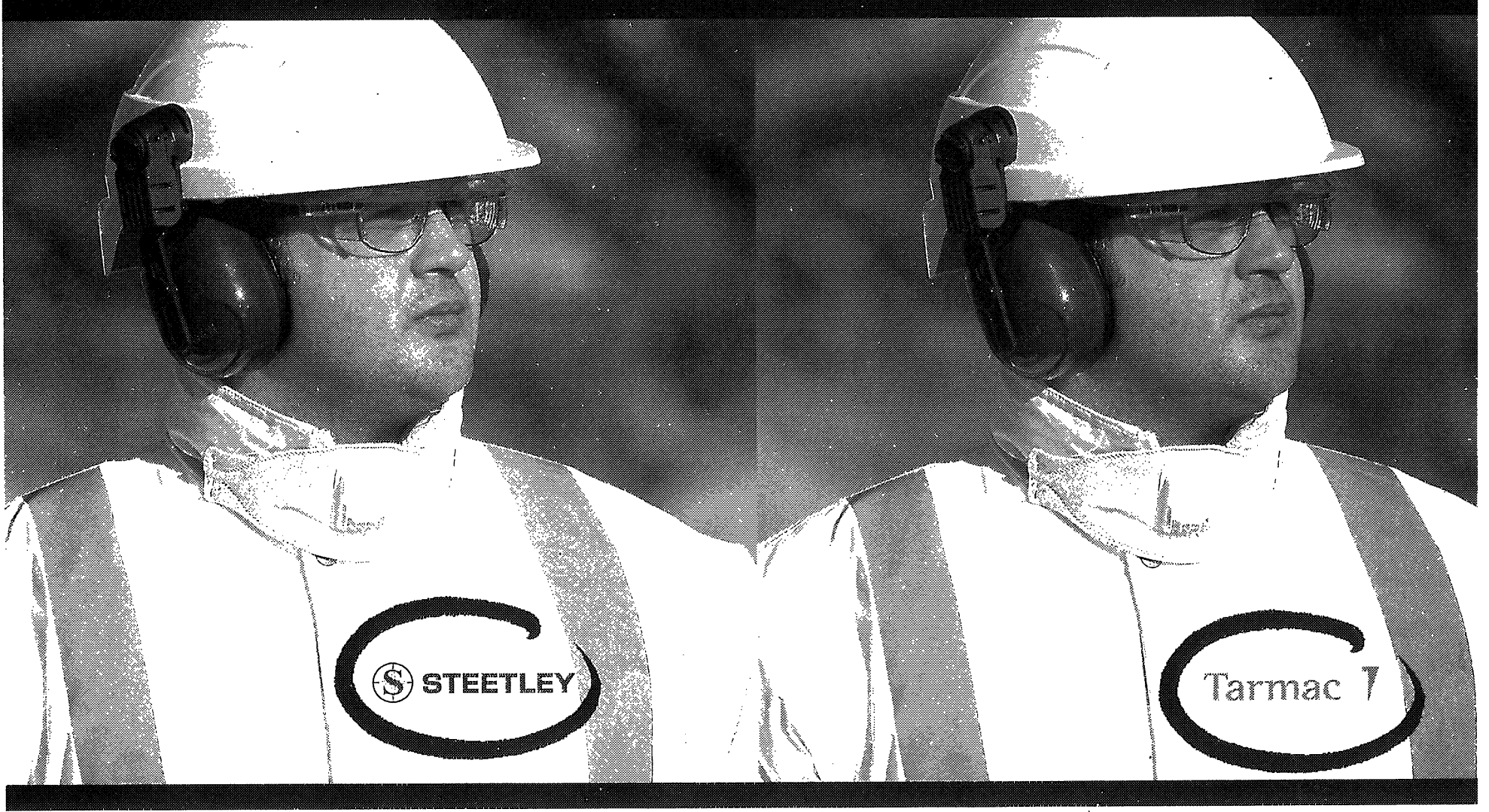

No busques más. Sólo hay esa

El grupo minero de impiantación mundial Anglo American pic al que pertenece STEETLEY IBERIA S.A.U., ha integrado en su estructura a la empresa TARMAC líder en suministro de materiales de construcción en el Reino Unido, que opera también en diferentes países de Europa y Asia.

Por razones de uniformidad corporativa, se ha decidido que las empresas del Grupo que se encuadran en el sector de la fabricación y

HASTA AHORA

\section{\$ STEETLEY MAVIKE}

distribución de materiales pesados para la construcción adopten la denominación TARMAC.

Por este motivo, a partir del 1 de marzo de 2004, STEETLEY IBERIA S.A.U. y su marca MAVIKE se llaman TARMAC IBERIA S.A.U.

Este cambio no supone variación alguna en organización, instalaciones, política, ni planes de desarrollo.

DESDE AHORA

\section{Tarmac (1) TARMAC IBERIA}

